\title{
De Adorno a Marx: política e fetichismo
}

\section{Caio Vasconcellos*}

\section{Resumo}

O objetivo deste artigo é comparar aspectos das interpretações de Karl Marx em 18 brumário de Luís Bonaparte e no ensaio Teoria freudiana e o padrão da propaganda fascista de Theodor Adorno, a respeito do caráter fetichista que se incorpora a instituições e fenômenos políticos no mundo burguês - tanto em sua aurora, quanto em seu desenlace tardio. Em ambas as interpretações há uma curiosa reincidência de personagens e certos procedimentos que estimulariam o povo a agir como massa. Se é possível sublinhar, nas análises de Marx sobre a ascensão de Luís Bonaparte, consequências para a centralização e racionalização do aparato estatal, ressalta-se, por outro lado, o aspecto mitológico e fantasmagórico que organizaria o interior da esfera política. Ao perscrutar o fenômeno do nazifascismo e do antissemitismo moderno, Adorno desenvolve uma interpretação a respeito das bases objetivas e dos mecanismos subjetivos envolvidos na dinâmica da relação entre o líder fascista e a massa de seus seguidores. Também aqui se verifica a atuação de fenômenos fetichizados.

Palavras-chave: Karl Marx, Theodor Adorno, política, fetichismo, sociedade de massa.

* Universidade Estadual de Campinas, Campinas, SP, Brasil. 


\section{From Adorno to Marx: politics and fetishism}

\section{Abstract}

This article aims to compare aspects from Karl Marx's The Eighteenth Brumaire of Louis Bonaparte and from Theodor Adorno's essay Freudian theory and the pattern of fascist propaganda, seeking to emphasize elements that would underline a fetishistic character integrated to institutions and political phenomena in the bourgeois world - both at its dawn and in its late outcome. In both interpretations, there is a curious recurrence of characters and schemes that would encourage people to act as a mass. If, on the one hand, it is possible to emphasize in Marx's analysis of the rise of Louis Bonaparte consequences of the centralization and rationalization of the state apparatus, on the other hand, it is possible to emphasize the mythological and phantasmagorical aspect that seem to organize the inside political sphere. By scrutinizing the phenomenon of Nazism and modern anti-Semitism, Theodor Adorno develops an interpretation about the objective bases and the subjective mechanisms involved in the dynamics of the relationship between the fascist leader and the mass comprised by his followers. Here, too, eminently fetishized phenomena are observed.

Keywords: Karl Marx, Theodor Adorno, politics, fetishism, mass society.

\section{Introdução}

Mentiras têm pernas longas: elas se antecipam ao tempo. Theodor Adorno, Minima moralia.

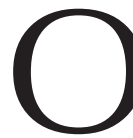
objetivo deste artigo ${ }^{1}$ é apresentar um diálogo entre aspectos das interpretações de O 18 brumário de Luís Bonaparte, de Karl Marx, e das análises de Theodor Adorno sobre os fenômenos do nazifascismo e do antissemitismo moderno, sobretudo em seu ensaio Teoria freudiana e o padrão da propaganda fascista, de 1951. Embora não haja referência do frankfurtiano ao livro de Marx, é possível notar nos autores um mesmo intuito de perscrutar os modos de manifestação de um

\footnotetext{
${ }^{1}$ Agradeço a Carlos Pissardo, a Rafaela Pannain e aos colegas do Grupo de Pesquisa Teoria Crítica e Sociologia da Unicamp pela leitura e comentários a este artigo. A pesquisa que serviu de base para sua elaboração contou com o financiamento da Fapesp (processo n. 2010/00422-4) e DAAD.
} 
encantamento fetichista que se cristalizaria na esfera da política, tanto na aurora das sociedades modernas quanto em seu decurso tardio.

De maneira direta, a mecânica de determinadas práticas e discursos dos tempos de Luís Bonaparte parece repisada nas performances dos líderes fascistas, principalmente na ambivalência de suas figuras - o bufão que se apodera do centro do poder político - e nos procedimentos de personalização e de estereotipia que, conforme o frankfurtiano, seriam próprios a situações nas quais o povo é conclamado a agir como massa.

Assim, após uma exposição de elementos-chave das análises de Marx, o propósito é concentrar-me na abordagem adorniana acerca dos pressupostos subjetivos e dos mecanismos objetivos que levariam os indivíduos a aderirem aos discursos e às práticas fascistas. Diante dessa constelação de fenômenos, gostaria de articular as discussões a algumas considerações de natureza política no pensamento de Adorno - sobretudo, a partir de suas reflexões sobre as democracias de massas.

\section{Centralização do aparato estatal}

A conjuntura sobre a qual Marx elabora um dos mais precisos diagnósticos é um momento de inflexão importante na história da dominação burguesa. Os desdobramentos da luta de classes na França assumiam um aspecto agonizante no período entre a revolução de fevereiro de 1848 e o golpe de dezembro de 1851. Em meio a reviravoltas constantes e hiatos de calmaria, partidos e grupos políticos se digladiavam nas ruas, na antessala dos gabinetes, no parlamento e nas demais instâncias de poder por miudezas administrativas e pelos mais altos cargos na burocracia estatal, pela extensão - ou supressão - de leis ordinárias e de cláusulas constitucionais e pelo próprio significado da palavra república.

Se, em um primeiro plano, esse regime de desassossego se expressaria como uma miscelânea de termos e condutas políticas, quando visto pelo prisma do materialismo histórico, ele espelha a natureza antinômica da própria sociedade burguesa. Assim, caso fosse possível resumir um evento 
social intenso, o desenlace da ascensão de Luís Bonaparte poderia ser interpretado como uma transformação decisiva na esfera da política do mundo burguês - a entrada do estado moderno na arena dos conflitos sociais. Embora longe de ser resultado de um coup de maître, a centralização da autoridade e do poder no órgão executivo inaugura uma nova maneira de lidar com a dinâmica de antagonismos entre as classes sociais peculiares ao capitalismo moderno.

Se suas instituições liberais já não se mostravam capazes de absorver o conteúdo social das reivindicações populares, a lealdade às convicções ideológicas entre os grupos dominantes teve de se readequar à regra da maior conveniência econômica. Diante de cisões que, cedo ou tarde, converteriam a luta pelo estado em luta contra o capital, a paz social só poderia ser restabelecida quando se abandonassem fantasias acerca de um regime político coerente com os modos de vida modernos - isto é, o regime parlamentar, em que tudo se decide democraticamente pela maioria - e superassem as reticências com uma forma de governo alheia, dispendiosa e que, por vezes, contrariava alguns de seus interesses mais imediatos, mas que nunca colocava em risco as fontes sociais de sua riqueza - pois o preço para salvar a sua bolsa era a coroa ser arrancada de sua cabeça (Marx, 2011).

Em meio a essas turbulências, Luís Bonaparte encena uma nova personagem pelos lados da reação, e desequilibra o jogo das tensões políticas. Ante a parcela mais numerosa da sociedade francesa - a massa do campesinato - que apenas partilha entre si a má sorte de uma periclitante situação econômica e social, a sua figura emerge como a encarnação da capacidade de determinação dos destinos, fazendo ecoar sua voz para o conjunto da população - seja com frases ocas e promessas vazias para o eleitorado comum, seja com "charutos e champanhe, carne de aves e salsichão" aos oficiais do exército (Marx, 2011, p. 94).

Dando esteio material à sua ascensão, a política do sabre que derrotara o proletariado nas famigeradas jornadas de junho de 1848 se transubstanciava em política de Estado. Em meio ao fortalecimento e à unificação das armas 
no chefe do executivo, uma casta artificial com interesses existenciais na preservação de seu regime se asperge por todos os poros da sociedade. Assumindo uma nova agenda administrativa e tantas outras tarefas de coerção social, essas forças policiais, militares e de burocratas tornam-se os braços e os olhos de um inaudito aparato de poder. Interpondo-se em todos os conflitos para debelar focos de rebeldia e preservar a integridade de suas instituições, esta ultra capilarizada estrutura estatal sustenta o manto imperial sobre os ombros do sobrinho de Napoleão Bonaparte, e a farsa amplia as dimensões de uma velha tragédia. Segundo Marx,

Esse Poder Executivo com a sua monstruosa organização burocrática e militar, com a sua máquina estatal multifacetada e artificiosa, esse exército de funcionários de meio milhão de pessoas somado a um exército regular de mais meio milhão, essa terrível corporação de parasitas, que envolve o organismo da sociedade francesa como uma membrana e entope todos os seus poros, surgiu no tempo da monarquia absoluta, na época da decadência do sistema feudal, para cuja aceleração contribuiu. [...]. Todas as revoluções somente aperfeiçoaram a máquina em vez de quebrá-la. Os partidos que lutaram alternadamente pelo poder consideraram a tomada de posse desse monstruoso edifício estatal como a parte do leão dos despojos do vencedor (Marx, 2011, p. 140-141).

\section{As sombras que perderam seus corpos}

Todavia, esse diagnóstico não esgota a potencialidade da crítica marxiana. Além de interpretar as cisões entre as diversas frações de classe que dinamizam a vida social e de examinar fenômenos ligados a transformações internas ao aparato estatal, o autor também chama atenção para a expressão de processos de encantamento fetichista que assumem uma feição particular na esfera da política moderna.

Ainda que, já no prefácio à segunda edição do livro, Marx se contraponha às interpretações centradas no desempenho pessoal de Luís Bonaparte por meio das quais sua figura seria imerecidamente engrandecida, também é verdade que a sua debilidade subjetiva é elencada entre os fatores 
que explicam a sua chegada triunfal ao poder. O homem que derrotou a burguesia republicana na luta contra a Assembleia Constituinte, que venceu o parlamento francês e pulverizou o seu regime, que reinstaurou - de modo farsesco - um império, assombraria qualquer analista pela grandeza de seus feitos. Porém, o que de fato surpreende é que tudo isso teria sido conquistado não apesar de sua bufonaria, mas talvez justamente por conta dela.

Paródia de um tempo no qual a sociedade moderna voltava à luz sua face mais progressista, Luís Bonaparte coroa um horizonte de sombras. Enquanto, na construção do novo, os homens, os acontecimentos e as instituições se cobriam com símbolos de antigas vitórias para se impregnar de legitimidade, essa volta à mitologia assume um significado distinto quando se trata de perpetuar o que já estaria em ruínas.

É diferente se a frase vai além do conteúdo para impulsionar rupturas em práticas e normas tradicionais, e se a frase fica aquém da coisa, com o único propósito de repisar aquilo que se reproduz sem viço. A fim de vencer suas batalhas contra o feudalismo, a burguesia tomou os seus valores como motes para não deixar esmorecer o entusiasmo nessas lutas e dirimir certas dúvidas sobre o alcance de seus ideais. Após o mundo burguês estar assentado em suas práticas, o reavivamento de figurinos de outrora, de palavras velhas de ordem e de bandeiras do passado faz saltar aos olhos os artifícios de uma fantasmagoria objetiva.

Já não se trata de confrontos entre falsas consciências, que apenas denotam a parcialidade inerente a cada uma delas. A verdadeira questão é a objetividade social sedimentada como segunda natureza, intervertendo as visões de mundo e os valores burgueses no seu oposto - a república francesa populariza o conceito de estado de sítio, e a campanha pelo sufrágio universal culmina em uma ditadura plebiscitária. Expressandose como fetiche, a insossa teatralidade de uma ópera bufa, o prestígio de uma caricatura e suas frases altissonantes e esvaziadas de significado concreto retratam as entranhas de uma ordem na qual os processos sociais 
mais decisivos se dão às costas dos indivíduos, e a dinâmica da sociedade sedimenta em uma nova estática.

Ante tal contexto, Luís Bonaparte larga na frente. As deficiências intelectuais, o vício de caráter e a propensão à gatunagem e ao parasitismo social que partilha com sua base social mais imediata, o lúmpen da "Sociedade de 10 de Dezembro", são vantagens comparativas na busca por novos seguidores - a partir de então, as lutas sociais podem ser conduzidas de modo infame (Marx, 2011). Ora como milícia, ora por dispositivos mais sutis, essa cambada arregimenta multidões em favor de uma sedição contra os poderosos, que eles juram promover.

Desassistida em seu cotidiano, uma numerosa parcela da população se aglomera feito massa atrás daquele que não consegue esconder seu caráter grotesco. Objetivamente incapazes de representarem por si os seus interesses, coleções de indivíduos e de grupos isolados prostram-se diante dos discursos e das fanfarronices de Luís Bonaparte, pois vivenciam uma situação de menoridade social e política que não é natural e tampouco se prende a causas subjetivas, mas é marca da indignidade de toda uma época.

Que a agudização das desigualdades socioeconômicas não tenha tido força suficiente para unir o campesinato e o proletariado urbano sob as égides do socialismo e destroçar seus verdadeiros inimigos - o capital e a máquina estatal - é talvez o primeiro exemplo histórico de que o poder da fraseologia lança um encanto mais arrebatador do que o chumbo. Segundo Marx,

Todo um povo, que por meio da revolução acreditava ter obtido a força motriz necessária para avançar com maior celeridade, de repente se vê arremessado de volta a uma época extinta e, para que não paire nenhuma dúvida quanto ao retrocesso sofrido, ressurgem os velhos elementos, a velha contagem do tempo, os velhos nomes, os velhos editais que já haviam sido transferidos ao campo da erudição antiquária e os velhos verdugos que pareciam ter-se decomposto há muito tempo. [...]. Enquanto faziam a revolução, os franceses não conseguiam deixar de pensar em Napoleão, como ficou comprovado na eleição de 10 de dezembro. Em meio às vicissitudes da revolução, sentiram saudades das panelas de carne do Egito e o dia 2 de dezembro de 1851 foi 
a resposta a isso. Agora eles não têm a caricatura do velho Napoleão, mas também o próprio Napoleão caricaturado em atitude condizente com os meados do século XIX (Marx, 2011, p. 27-28).

Malgrado o contexto socio-histórico distinto e a inconveniência de saltar quase um século na história social moderna, pode-se encontrar uma caracterização bastante similar ao jogo de sedução de Luís Bonaparte, porém acerca de determinados fenômenos e personagens na esfera da política em meados dos anos 1940. Baseado em pesquisas levadas a cabo por membros do Instituto de Pesquisa Socia/2, Adorno ([1951] 2015) chama atenção para dois aspectos que se verificariam com grande frequência em discursos e panfletos de agitadores fascistas estadunidenses daquela época.

Em primeiro lugar, esses materiais de propaganda se singularizariam pela quase ausência de menção a questões políticas concretas - excetuando-se disparates como o envio de alienígenas para campos de concentração e a expatriação de sionistas. Além disso, seria possível reconhecer um método de conduta, composto por rígidos procedimentos gestuais e discursivos, que se repetia continuamente. Ainda que pudessem assumir diferentes roupagens como a do antissemita clássico, a do cristão conservador ou até a que emularia jargões de revolucionários, e adotar uma linguagem mais ou menos cifrada com relação às suas vítimas, esses agitadores se mostravam como figuras verborrágicas, com traços paranoicos inequívocos e que, para atiçar ódio contra seus alvos, mimetizam alguns de seus modos de vida, costumes morais e supostas particularidades físicas. Por expedientes tão rústicos, esses discursos buscavam não apenas mobilizar multidões, mas incliná-las a uma ação violenta e sem qualquer objetivo político sensato.

${ }^{2}$ Neste ensaio de 1951, Adorno cita os livros Prophets of deceit e Portrait of the American agitator, ambos de Leo Löwenthal e Norbert Guterman. Além da clássica reconstrução histórica realizada por Wiggershaus (2002) sobre a centralidade de pesquisas e reflexões sobre o antissemitismo entre os frankfurtianos, cito o trabalho de Helmut König (2016) que analisa minuciosamente as dimensões econômicas, históricas, religiosas e psicológicas da interpretação de Adorno e Horkheimer no capítulo "Os elementos do antissemitismo" de Dialética do esclarecimento. 
Embora a adesão ao ideário e às práticas fascistas não fosse um fenômeno puramente psicológico, o interesse do frankfurtiano recai sobre os motivos subjetivos de tal conformação. Pois, mesmo que Hitler e seus congêneres apenas representassem interesses políticos e econômicos mais profundos, a mentalidade fascista precisa da figura e do jogo de sedução de seu líder para cumprir o seu propósito - abolir a democracia pelo apoio das massas contra o princípio democrático (Adorno, 2015).

Com espírito idêntico ao que distinguiria as interpretações de Sigmund Freud a respeito do comportamento violento, da exaltação de afetos e da inibição do pensamento associados às massas das análises de Gustave Le Bon, Adorno interroga sobre as bases psicossociais de uma situação na qual sujeitos modernos, em plena posse de suas faculdades cognitivas, se tornam afeitos a mensagens de forma e de conteúdo tão regressivos. Não se trata de uma herança arcaica que persistiria nas condutas humanas a despeito de todos os progressos da civilização. Mais propriamente, o seu real fundamento se alicerça em um encantamento fetichista promovido no seio da ordem social que faz com que indivíduos modernos se portem como membros de uma turba.

Se, na aurora da modernidade, Georg Simmel elencava a experiência do choque e o florescimento de uma atitude blasé como marcas da subjetividade moderna, a ordem subsequente das coisas desencadeia outras reações. Aquela indiferença com relação a qualquer diferença parece ter sido suspensa por quem se particulariza entre as massas.

Como Hitler, que aparecia ao público como um misto de King Kong e barbeiro de subúrbio - alguém forte e poderoso e que, ao mesmo tempo, transparece ser o mais comum dos homens -, a ambivalência constitutiva da personalidade do líder fascista dá resposta a certos conflitos subjetivos. Expostas a novos e continuados abismos, essas massas encontrariam refúgio para seus temores cotidianos na figura idealizada de um ameaçador pai primitivo que catalisa erupções de revolta contra a civilização. Nessa insurgência, a crítica ao princípio de expropriação da forma salário é ofuscada pelo estímulo a um ódio difuso contra a esfera da aparência socialmente 
necessária de todo o processo de reprodução das desigualdades de classe - "as pessoas gritam: 'pega ladrão!' e apontam para o judeu" (Adorno; Horkheimer, 1985, p. 169).

O massivo engajamento subjetivo denuncia a amplitude da barbárie; o caráter simplório do ardil, a sua real dimensão. Embora os seguidores mais cativos não se colocassem em dúvida sobre quem deverá dar as cartas do jogo, a cega obediência a quem é também tão risível ilude sobre quem é a verdadeira fonte de autoridade. Uma mesma regressão social se assenta em personalidades autoritárias por meio das quais a vontade insaciável de mando é acompanhada pelo não menos incontido anseio subjetivo à submissão. Longe de ser indício de uma ordem social que perdia sua capacidade de persuasão ideológica, a mecânica de tal encantamento fetichista parece ter plasticidade suficiente para sobreviver às intempéries que ela própria promove por sua imanência. Segundo Adorno,

[...] um dos dispositivos básicos da propaganda fascista personalizada é o conceito de "pequeno grande homem", uma pessoa que sugere tanto onipotência quanto a ideia de que é apenas um do povo, um norte-americano pleno e viril, não maculado por riqueza material ou espiritual. A ambivalência psicológica auxilia a operar o milagre social. A imagem do líder satisfaz o duplo desejo do seguidor em se submeter à autoridade e ser ele mesmo a autoridade. Isso convém a um mundo em que o controle irracional é exercido ainda que tenha perdido sua evidência interna devido ao esclarecimento universal. As pessoas que obedecem aos ditadores também percebem que estes são supérfluos. Elas reconciliam essa contradição ao assumirem que elas mesmas são o opressor brutal (Adorno, 2015, p. 172).

\section{"Olho pedra, vejo pedra mesmo"}

A fim de compreender os fundamentos dessa mecânica, Adorno busca o conteúdo social sedimentado em conceitos da psicanálise freudiana. Se a antiga neurose da histeria de conversão dera um impulso inicial às suas formulações, o crescente interesse de Freud pelas problemáticas do narcisismo e da paranoia no entreguerras europeu anteciparia os 
fundamentos de uma grave crise nas entranhas da psique individual, que eclodiria na década seguinte. Embora as categorias freudianas se voltassem para as relações internas de dois grupos organizados - o Exército e a Igreja -, o decisivo para Adorno estaria na disposição de Freud em perscrutar nas profundezas da subjetividade humana os motivos da propensão a se subjugar de maneira irrefletida a coletividades, o que, segundo o frankfurtiano, também caracterizaria o fenômeno do nazifascismo.

Mais do que uma submissão a um órgão centralizado e estruturado de cima a baixo, o tipo de ligação estabelecida entre os seguidores e deles com relação ao líder é o que explicaria a regressão a condutas comuns a selvagens, crianças e neuróticos em indivíduos modernos e, a princípio, autônomos. O vínculo libidinal que os arregimenta seria expressão de antinomias internas às suas dinâmicas pulsionais, sobretudo aquelas formadas a partir das contradições entre as promessas utópicas que a modernidade capitalista suscita e, ao mesmo tempo, reprime, por hipostasiar relações sociais e de propriedade que há muito perderam suas justificativas racionais.

Hitler, as suas tropas e aqueles que participavam de seus ritos padeceriam de uma mesma patologia em sua psique. De origem social, ela não pode ser pensada como decorrência de um distúrbio fisiológico qualquer, mas como uma ampliação desmesurada de conflitos que atuariam na formação subjetiva moderna padrão - o Eu como órgão de identidade autocentrada é a raiz do problema e não a sua mera dissolução ou seu enfraquecimento ${ }^{3}$.

Tal com nos processos de amadurecimento individual, nos quais as exigências de satisfação das pulsões são mediadas pela internalização de princípios de conduta de um ideal de Eu e de dispositivos de repressão pulsional das instâncias do Super-eu, os líderes dos modernos movimentos

${ }^{3}$ Acerca desse tema, Gabriel Cohn chama atenção para uma passagem decisiva de Dialética do esclarecimento. Em "Esclarecimento e ofuscação: Adorno \& Horkheimer hoje", Cohn afirma: "O modo de comportamento antissemita é desencadeado em situações nas quais 'indivíduos ofuscados e privados da sua subjetividade se vêem à solta como sujeitos', escrevem eles em passagem fundamental. Aqui temos reunidos três termos do problema armado pelos autores: a ofuscação, a condição de indivíduos serem privados da sua subjetividade e mesmo assim serem levados a agir como se fossem sujeitos, e este outro termo central no argumento, que é o de estar posto 'à solta'." (Cohn, 1998, p. 8). 
de massa cumpririam uma função homóloga à da figura de autoridade no interior dos modos de sociabilização da família tradicional burguesa - o pai como representante de uma ordem fundada a partir do interdito ao primeiro objeto de investimento libidinal da criança e também aquele que não se submete a essa proibição. Além da possibilidade de composição de vínculos mais amplos na comunidade formada pelos irmãos, essas figuras míticas colocam em cena processos capazes de suscitar consequências distintas ao estimular outros afetos entre seus herdeiros. Em Psicologia das massas e análise do Eu,

O pai primordial havia impedido os seus filhos de satisfazerem seus impulsos sexuais diretos; obrigou-os à abstinência e, por conseguinte, ao estabelecimento de laços afetivos com ele e entre si, que podiam resultar dos impulsos da meta sexual inibida. Ele os compeliu, por assim dizer, à psicologia da massa. Seus ciúmes sexuais e sua intolerância vieram a ser, em última análise, as causas da psicologia da massa (Freud, 2011, p. 68).

Pois, embora essa dinâmica pareça somente preservar contratendências à reprodução de vínculos sociais endógenos, os parâmetros posteriores das relações dos homens com seus desejos são também estabelecidos pela identificação com esse ideal do Eu que, quando é forte em demasia, suscita impulsos narcisistas imanentes à formação dos indivíduos modernos ${ }^{4}$. Ao percorrer o mundo em uma incessante procura por algo como ele mesmo, esse sujeito se fecha às nuances da empiria, passando a perceber como ameaça tudo aquilo que não lhe seja idêntico - e "toda a cólera

\footnotetext{
${ }^{4}$ Há uma importante diferenciação interna ao conceito de narcisismo em Freud. Se, no narcisismo primário, não há ainda uma noção de Eu como unidade autorreferente e as experiências de satisfação estão diretamente atreladas às atividades vitais de autoconservação, no narcisismo secundário, a passagem em direção ao investimento libidinal no objeto regride a uma situação na qual o indivíduo toma a própria imagem do seu Eu como objeto. Segundo Pissardo, "Já o narcisismo secundário refere-se a um processo de retorno (pelo menos aparentemente) da libido objetal ao eu. Nesse caso, a libido abandona o desejo de satisfação nos objetos (pessoas e coisas do mundo exterior) e volta-se para seu próprio eu. Não por acaso, Freud associa o narcisismo ao luto e à melancolia, resultantes ambos da perda do objeto amoroso. Diferentemente, entretanto, dos neuróticos, que 'iludem' o desejo de objetos reais perdidos por meio de sintomas, o narcisista retira-se do mundo em busca de satisfação em si próprio. Daí o delírio de grandeza." (Pissardo, 2011, p. 178).
} 
é descarregada sobre os desamparados que chamam atenção" (Adorno; Horkheimer, 1985). Segundo Adorno,

O ganho narcísico fornecido pela propaganda fascista é óbvio. Ela sugere continuamente, e algumas vezes de forma maliciosa, que o seguidor, simplesmente por pertencer ao in-group, é melhor, superior e mais puro que aqueles que são excluídos. Ao mesmo tempo, qualquer tipo de crítica ou de autoconsciência é ressentida como uma perda narcísica e incita fúria. Isso explica a violenta reação de todos os fascistas contra o que eles julgam zersetzend [destrutivo], aquilo que desmascara seus valores mantidos obstinadamente, e também explica a hostilidade de pessoas preconceituosas contra qualquer tipo de introspecção (Adorno, 2015, p. 177).

Então, o líder fascista surge como falso modelo de liberdade subjetiva - o pai primitivo é o ídolo da massa, aquele que domina o Eu ao assumir o lugar de ideal do Eu (Freud, 2011). Ao expor uma personalidade eivada de preconceitos e afeita a condutas violentas, ele aparece como alguém que está acima dos tabus sobre os quais se assentam a civilização e o mundo modernos.

Se, na satisfação das paixões humanas, uma incontornável opacidade se interpõe entre a eleição de qualquer objeto de desejo e o seu posterior desfrute, o antissemitismo atropela esse desencontro. Por meio de suas lentes oblíquas, as formas de existência são deturpadas até que correspondam ao delírio de seus jargões. As particularidades econômicas, políticas e culturais do lado dos facciosos são abstraídas em prol do mito da pureza da raça ariana, e entre as suas vítimas aquele que é apontado como inimigo é logo percebido como inimigo.

Mesmo que a hierarquia do partido agrave as suas distinções internas de classe, a incapacidade de se aperceber dessas clivagens pulsa no coração de uma mesma subjetividade narcisista que particulariza as lideranças fascistas e seus seguidores. A energia devotada ao Führer nada mais é do que a idolatria a uma imagem idealizada deles próprios. Socialmente incapacitados de estabelecer uma experiência concreta entre si e com as coisas, massas de indivíduos encontram satisfação em uma sombra projetada 
a partir do seu Eu empírico que busca se depurar das manchas de suas frustrações cotidianas (Adorno, 2015).

Esgueirando-se pela mecânica desses itinerários subjetivos, os procedimentos de personalização e de estereotipia nos panfletos de propaganda fascista reverberam na consciência e na inconsciência de multidões. Proferido por alguém que corporifica essas massas, o incessante propagandear de clichês toma o lugar de uma indagação sobre causas concretas das iniquidades sociais que assolam suas vidas. Ainda que fosse evidente que os judeus não eram a origem de todos os males e que a guerra total e continuada contra os dois colossos mundiais que se formavam levaria a uma derrota incontornável e nova ruína econômica, nada abalaria as suas convicções.

Seja pelo morticínio, seja por vias simbólicas, a recorrente inadequação entre os preconceitos antissemitas e a realidade é compensada pela repetição de práticas compulsivas. Se, na estrutura de um pensamento sadio, o polo subjetivo se abre a uma experiência concreta de conhecimento por meio da qual se estabelece uma síntese dialética entre suas impressões e sensações primárias e os juízos e conceitos fornecidos pela esfera objetiva, a instrumentalização antissemita da razão apenas confere coerência lógica a uma falsa projeção.

$\mathrm{O}$ rito de eleger um bode-expiatório, ridicularizar seus jeitos e seus modos de ser e, enfim, oferecê-lo em sacrifício ofusca a faculdade humana de julgamento com abstrações de efeitos tenebrosos - um discurso paranoico se assenta como norma racional do mundo e a imagem fantasiosa do judeu serve de pretexto para sua aniquilação real.

Não obstante o patente arcaísmo, a situação seria moderna por excelência. Desde suas origens, o modo capitalista de produção e de troca de mercadorias já demonstrava um radical desinteresse pelo que não se impregnasse de ares de similitude, isto é, de sua fantasmagoria específica que garantiria às coisas certa objetividade social. Em meio às ruínas da antiga ordem liberal, esse princípio geral de equivalência desencadeia uma nova 
reação - quem, entre nós, parece ser diferente é tratado como estranho e, apenas por isso, torna-se merecedor do pior dos destinos.

Se toda mercadoria é portadora de um segredo que a faz aparecer em sua forma social objetiva como dotada de características fisicamente metafísicas e não como produto do trabalho humano, o antissemita enxerga fundamentos biológicos em diferenças culturais, uma necessidade objetiva na pilhagem das propriedades judaicas e o destino de um povo na invasão de outros países. Muito embora a vida social não necessite se organizar de maneira tão mesquinha e tampouco os judeus correspondam à sua falsa e indecorosa caricatura, o verdadeiro problema é que os antissemitas agem como se acreditassem - e, na prática, passam a acreditar verdadeiramente ${ }^{5}$. Segundo Adorno,

As pessoas acreditam tão pouco, do fundo de seu coração, que os judeus são o demônio, quanto acreditam completamente em seu líder. Elas não se identificam realmente com ele, mas representam [act] essa identificação, encenam [perform] seu próprio entusiasmo, e assim participam na encenação [performance] de seu líder. É através dessa encenação que elas atingem um equilíbrio entre seus ímpetos pulsionais continuamente mobilizados e o estágio histórico de esclarecimento que elas alcançaram e que não pode ser revogado arbitrariamente. É provavelmente a suspeita desse caráter fictício de sua própria "psicologia de grupo" que torna as multidões fascistas tão impiedosas e inalcançáveis. Se elas parassem para refletir por um segundo, toda a encenação se despedaçaria e elas entrariam em pânico (Adorno, 2015, p. 188).

\footnotetext{
${ }^{5}$ Por meio de um consentimento cínico e esvaziado de sentido, o antissemitismo expande suas fronteiras para além de seus pares, e dá forma a outras configurações e a uma nova função da ideologia. Esta já não buscaria mais elidir acerca de seus pressupostos materiais que a põem em funcionamento, mas estabelece um modo irônico de justificação da efetividade social. Para uma instigante discussão sobre essa questão na obra de Adorno e a respeito das transformações que tal compreensão da ideologia implica na crítica do frankfurtiano, cito o capítulo "Sobre um riso que não reconcilia" de Vladimir Safatle (2011).
} 


\section{Líderes e democracia para as massas}

Considero a sobrevivência do nacional-socialismo na democracia como potencialmente mais ameaçadora do que a sobrevivência de tendências fascistas contra a democracia.

Theodor Adorno, O que significa elaborar o passado.

Tal como a perspectiva benjaminiana de que, na tradição dos oprimidos, o estado de exceção é, na verdade, sua regra (Löwy, 2005), Adorno se ocupa com a sobrevivência de personagens e fenômenos homólogos no período de normalidade democrática do imediato pós-guerra. Não que se trate de algo específico aos países do eixo. Nos primeiros dos anos que, posteriormente, ficariam conhecidos como as décadas douradas do capitalismo moderno, o frankfurtiano sublinha a permanência de muitas das condições sociais objetivas que haviam levado o mundo à barbárie. Se a realização do novo imperativo categórico legado por Hitler e seu regime - isto é, orientar o pensamento e a ação para que Auschwitz não se repita (Adorno, 2009) - depende, em última instância, da capacidade de resistência subjetiva a submeter-se por mais uma vez àqueles disparates, o elevado grau de impotência que os indivíduos continuam a vivenciar no dia a dia se erige como obstáculo para a eliminação dos resquícios do nazifascismo e para a implementação de uma ordem democrática de direito e de fato ${ }^{6}$.

Ora, com a reprodução da sociedade presa aos processos de autovalorização do valor, os destinos da vida privada, da liberdade subjetiva e de sua realização na esfera política se restringem aos grilhões de uma

\footnotetext{
${ }^{6}$ Embora certa matriz de comentadores aponte para um progressivo afastamento de uma reflexão atinada às especificidades socio-históricas das sociedades modernas desde a publicação de Dialética do esclarecimento (Benhabib, 1996), e ressalte uma espécie de déficit sociológico, sobretudo nos textos tardios de Adorno (Honneth, 1993), a crítica adorniana não documenta somente a situação de empobrecimento subjetivo em uma ordem social conduzida por colossos econômicos e camarilhas de lideranças carismáticas. A denúncia de sua forma e de seu conteúdo regressivos também pavimenta um dos caminhos pelos quais Adorno assume uma relação mais explícita com a prática social - tanto para pensar os limites concretos da ação política nessas democracias como para refletir sobre os rumos para uma sociedade emancipada.
} 
engrenagem articulada sem qualquer apreço à satisfação concreta das necessidades humanas. Mesmo que o modelo de intervenção estatal se mostrasse bem-sucedido para evitar crises econômicas e acontecimentos como o da sexta-feira negra de 1929, a aceleração do desenvolvimento em moldes capitalistas, as políticas de pleno emprego e o aumento do nível de renda de certos segmentos da população deixavam intocadas as bases sociais de produção de assimetrias entre as classes, ainda que as antigas formas de suas desigualdades tivessem desaparecido em sua superfície (Adorno, 2010).

Enquanto o bem-estar material e a saciedade de uns se mostrarem dependentes de uma situação em que muitos continuem sem ter o que comer (Adorno, 2011), o princípio da soberania popular só poderá ser implementado na medida em que for tolhido em sua raiz. Longe de se consolidar como espaço da mais ampla liberdade humana, a democracia se justifica nos termos de seu sucesso ou insucesso em promover crescimento econômico. Deixando a forma capitalista de produção fora do alcance das urnas, o modo de ordenação das relações políticas se petrifica como um arremedo subordinado à insaciedade de valores alheios - é a política que permanece vítima do mundo das finanças, e não o seu contrário.

Por mais uma vez, as sociedades modernas se mostram como ambiente propício para a emergência de novos líderes de massa. Isso, porém, de um lado. De outro, é oportuno lembrar que Adorno também chamou atenção para contradições que poderiam levar a mecânica desse encantamento fetichista à implosão. É certo que, para enfrentar líderes de massas e suas fórmulas estereotipadas, não é suficiente apontar o ridículo de seus modos e o caráter difuso e irracional dos objetivos visados - o seu encanto advém dessa combinação. Atiçados para angariar séquitos, os afetos ligados à sensação de paralisia e de impotência que conduziriam indivíduos autônomos e racionais a se adaptarem, de maneira acrítica, a relações sociais petrificadas são promovidos pelo próprio modo de reprodução material dessas mesmas sociedades. 
Expor as contradições econômicas nas propostas de quem se apresenta como capaz de conduzir o conjunto de um povo eleito, mas, ao mesmo tempo, aprofunda as bases objetivas das desigualdades de classe e hipostasia uma situação de menoridade social pode fazer explodir o caldeirão do feitiço - a anatomia dessa mecânica também auxilia nessa tarefa. Em Democratic leadership and mass manipulation, Adorno coloca que

O trabalho do agitador consiste em astuciosamente conquistar seu apoio, posando como seu vizinho. Desse modo, porém, um motivo verdadeiramente humano, o anseio por amor, por relações genuínas e espontâneas, é apropriado pelos promotores de sangue-frio do inumano. [...]. Ainda que elas caiam nisso durante certo tempo, os desejos envolvidos são tão profundos, porém, que não há como elas serem [definitivamente] satisfeitas por essa impostura. Tratadas como crianças, as pessoas acabarão reagindo como tais e vindo a perceber que o tio que lhes fala como um bebê só o faz para melhor insinuar seus objetivos ulteriores. Por meio de experiências como essa pode ocorrer que a energia inerente a seus desejos finalmente se volte contra sua exploração (Adorno, 1986, p. 429).

\section{Considerações finais}

O diálogo entre Marx e Adorno revela certas continuidades entre suas interpretações. Urdida diante de impasses sociais e políticos na aurora do mundo burguês, a forma da sedução fetichista que levou Luís Bonaparte ao centro do poder reaparece, no decurso tardio da modernidade, na mecânica da relação entre os líderes fascistas e os seus seguidores. Seja para conter ameaças de rupturas revolucionárias, seja por malversar essas mesmas energias para preservar uma ordem que, ao se desintegrar, é tresloucada na realidade, essas personagens representam papéis decisivos quando a dinâmica da luta de classes se desdobra em um contexto de grave crise social. O fetiche que se apodera da esfera da política é espelho de uma situação de menoridade social vivenciada de forma cotidiana, e que a estrutura de um Estado forte e pesado ajuda a perpetuar. 
É oportuno ressaltar, por outro lado, particularidades nos diagnósticos dos dois autores. Se, nos eventos na França, Marx apostara na união entre camponeses e o proletariado urbano para debelar a trama que lançou uma figura risível ao centro do poder político, Adorno enfrenta um momento histórico no qual o engodo do nazifascismo encontrava apoio massivo entre trabalhadores e tantos outros segmentos populares. A oportunidade de um desenlace emancipado permanecia uma alternativa aberta. Todavia, as mais urgentes preocupações do frankfurtiano se concentraram na anatomia desse regressivo ativismo. Ainda assim, Adorno também refletiu sobre as possibilidades de escapar deste feitiço, e despedaçar esse encantamento que sustenta o todo.

Caio Eduardo Teixeira Vasconcellos é Doutor em Sociologia e atualmente pesquisador de pós-doutorado junto ao Departamento de Sociologia do IFCH da Unicamp.

Ð caiovascon@hotmail.com

\section{Referências}

1. ADORNO, Theodor. A teoria freudiana e o padrão de propaganda fascista. In: Ensaios sobre psicologia social e psicanálise. São Paulo: Editora da Unesp, 2015.

2. ADORNO, Theodor. Democratic leadership and mass manipulation. In: TIEDEMANN, Rolf; ADORNO, Gretel; BUCK-MORSS, Susan; SCHULTZ, Klaus (orgs.). Gesammelte Schriften, Bande 20. Frankfurt am Main: Suhrkamp Verlag, 1986.

3. ADORNO, Theodor. Dialética negativa. São Paulo: Jorge Zahar Editor, 2009.

4. ADORNO, Theodor. O que significa elaborar o passado. In: ADORNO, Theodor. Educação e emancipação. São Paulo: Paz e Terra, 2011.

5. ADORNO, Theodor; HORKHEIMER, Max. Dialética do esclarecimento. Fragmentos filosóficos. Rio de Janeiro: Jorge Zahar Editor, 1985.

6. BENHABIB, Seyla. A crítica da razão instrumental. In: ZIZEK, Slavoj (org.). Um mapa da ideologia. Rio de Janeiro: Contraponto, 1996.

7. COHN, Gabriel. Esclarecimento e ofuscação: Adorno \& Horkheimer hoje. Lua Nova: Revista de Cultura e Política, n. 43, p. 5-24, 1998. doi: 10.1590/S010264451998000100002 
8. FREUD, Sigmmund. Psicologia das massas e análise do eu e outros textos. São Paulo: Companhia das Letras, 2011.

9. HONNETH, Axel. The critical of power. Massachusetts: The MIT Press, 1993. 10. KÖNIG, Helmut. Elemente des Antisemitismus. Weilerswist: Velbrück Wissenschaft, 2016.

11. LÖWY, Michael. Walter Benjamin: aviso de incêndio. São Paulo: Boitempo Editorial, 2005.

12. MARX, Karl. O 18 de Brumário de Luís Bonaparte. São Paulo: Boitempo Editorial, 2011.

13. PISSARDO, Carlos. Os pressupostos materialistas da crítica à razão cognitiva na Dialética do esclarecimento. Dissertação [Mestrado em Filosofia], Faculdade de Filosofia, Letras e Ciências Humanas - FFLCH-USP, 2011.

14. SAFATLE, Vladimir. Cinismo e falência da crítica. São Paulo: Boitempo Editorial, 2011.

15. WIGGERSHAUS, Rolf. A escola de Frankfurt. História, desenvolvimento teórico, significação política. Rio de Janeiro: Difel, 2002.

Recebido: 26 mar. 2019

Aceito: 25 jun. 2019 